\title{
Landscape research in Switzerland: exploring space and place of a multi-ethnic society
}

Landschaftsforschung in der Schweiz: den Raum und seine Bedeutung für eine multi-ethnische Bevölkerung erkunden

Felix Kienast, Matthias Bürgi and Otto Wildi

\section{(2) OpenEdition}

Electronic version

URL: http://journals.openedition.org/belgeo/13782

DOI: $10.4000 /$ belgeo.13782

ISSN: 2294-9135

Publisher:

National Committee of Geography of Belgium, Société Royale Belge de Géographie

Printed version

Date of publication: 30 September 2004

Number of pages: 369-384

ISSN: 1377-2368

\section{Electronic reference}

Felix Kienast, Matthias Bürgi and Otto Wildi, « Landscape research in Switzerland: exploring space and place of a multi-ethnic society », Belgeo [Online], 2-3 | 2004, Online since 14 September 2013,

connection on 08 July 2020. URL : http://journals.openedition.org/belgeo/13782 ; DOI : https:// doi.org/10.4000/belgeo.13782

This text was automatically generated on 8 July 2020 .

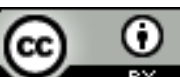

Belgeo est mis à disposition selon les termes de la licence Creative Commons Attribution 4.0 International. 


\section{Landscape research in Switzerland: exploring space and place of a multi-ethnic society}

Landschaftsforschung in der Schweiz: den Raum und seine Bedeutung für eine multi-ethnische Bevölkerung erkunden

Felix Kienast, Matthias Bürgi and Otto Wildi

\section{Some stimuli for landscape research in Switzerland}

1 In contrast to many other fields of research that are more or less independent of regional properties, landscape research is driven by both region-independent stimuli, and stimuli that have a strong bounding to the regional context. The latter are primarily responsible for the variety and variability of research themes of landscape research in Europe and throughout the world. Region-independent stimuli that have helped to break new grounds in landscape research are broadly discussed in Turner et al. (2001) and Bastian \& Steinhardt (2003). They include technological breakthroughs in remote sensing, ecophysiology and statistics or breakthroughs in systems analysis or social sciences. These topics have all influenced landscape research in Switzerland and have generated a multidisciplinary research field that enjoys a high technological and intellectual standard. Region-specific stimuli for landscape research in Switzerland can be summarized as follows:

2 - The highly variable and heterogeneous topography: The variety of physiographic and cultural conditions caused by the mountain terrain dictates identity and lifestyles and is a prerequisite to develop and test landscape-related theories, e.g. metapopulation theories, theories about human migration, population dynamics of plants and animals in time and space, or the evolution of landscape notions and value systems of the population. In spite of its small area, Switzerland has an astonishingly varied climate, brought about by its situation at the point of intersection of the main climatic regions of Europe: the oceanic, the northern European, the Mediterranean and the continental. 
Switzerland includes three physiographic regions (see Fig. 1): the Jura Mountains (about $10 \%$ of the area), the Central Plateau (30\%), and the Alps (60\%). Today, agriculture dominates $37 \%$ of the country's area, $31 \%$ are covered by forests, $7 \%$ include settlements and urban areas, and $25 \%$ are unproductive areas ${ }^{1}$. In the mountain part («Swiss Alps», see Fig. 1) tourism is the major source of income (Müller and Flügel, 1999). There is a on-going land-use segregation with intensive use of highly profitable land (urbanized parts in the Alpine valleys and tourist resorts) and abandonment of areas with low income. Permanent and temporary migration of people imposes a great challenge to the formerly isolated cultural entities. Hence loss of identification with the public space is not only a theme in the large urban parts but also in remote areas. Most of the Swiss population lives on the Plateau (see Fig. 1) in urban areas and periurban zones. Despite urbanization the environmental quality is high due to numerous landscape and nature protection activities at the local level («small-scale landscaping»). The so-called Jura (see Fig. 1) has a generous covering of woodland; indeed, the term Jura means wood in Celtic. The valley floors and the slopes are used mainly for arable farming, and the higher regions primarily for grazing. This part of Switzerland is known as one of the most fruitful places for technical, cultural and societal innovation (e.g. forming a new Canton in 1976). For more information on Swiss landscapes see corresponding Internet resources ${ }^{2}$.

Figure 1. Topography and major landscape types of Switzerland.

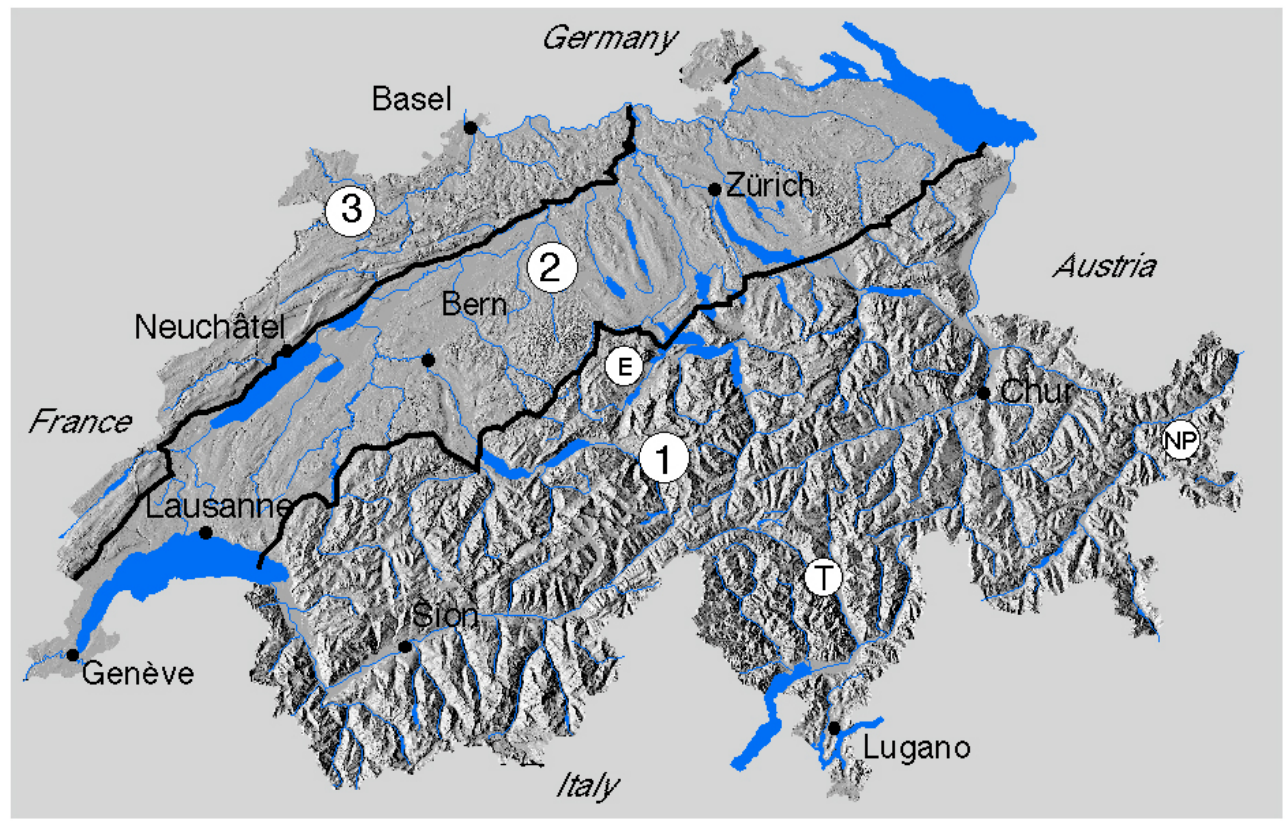

1. Swiss Alps; 2. Plateau; 3. Swiss Jura, as well as some locations of regions mentioned in the text (T: Ticino; E: UNESCO Biosphere Reserve Entlebuch; NP: Swiss National Park).

- The contrasting individualistic lifestyles of a multi-ethnic society: Switzerland is the result of a federalistic, multi-ethnic and multi-lingual land development policy that puts a great effort in preserving individualistic lifestyles. This cohabitation of various cultures results in contrasts of both the notions towards landscapes and the methods in landscape research. Swiss individualism seems to slow down implementation of mainstream global lifestyles but creates heterogeneity and niches in both landscapes and society. A typical example is the unique Ticino region in the mountainous southern 
part with a fairly independent cultural life (Fig.1, T). It's the traditional home of many political refugees in the 19/20th century, and the home of artists and philosophers ${ }^{3}$. These niches play an important role as a think tank for innovative and sometimes utopic land development schemes. Swiss land planning lives with the vision (and myth?) that the diversity of views about land-(use) and the corresponding public debates safeguard individual identification with the land and should therefore be one possible model for peaceful co-existence of different cultures (Marengo and Alaimo, 1998; Racine and Marengo, 2000). This urge to respect and conserve a variety of perceptions about land-(use) has shaped and modified this country, and it is one explanation for many individualistic decisions being taken.

4 - The long tradition of environmental research, monitoring and education and the high public motivation to support landscape research: The interest in mountain nature and nature observation goes back to the age of enlightenment in the 18th century, followed in the 19th century by early tourism and by the foundations of many research and observation stations that have generated species lists or long time-series in climatology, radiation or landscape resources. Due to successful environmental education programs by schools, NGOs and environmental protection agencies (Lindemann-Matthies, 1995, 2000, 2001) and the fact that unique landscapes are the most important resources for tourism, public awareness of environmental problems and landscape issues is high, but only as long as it does not touch the individual lifestyle: Thus large amounts of money are funneled into subsidizing small-scale landscape and biotope conservation at the community level, whereas large-scale conservation schemes that would require strong centralized legislation, are weak. The only exceptions to that rule are the Swiss National Park with an area of approx. 170 $\mathrm{km} 2$, the recently declared biosphere reserve Entlebuch (Fig.1 NP, E) ${ }^{4}$, and the wetland landscape protection act that ensures conservation of approximately 80 larger landscape complexes that are dominated by wetlands (Hintermann, 1991; Locher, 1991). Technical measures for landscape protection enjoy a wide acceptance in the population. This might also be the reason why the public supported several referendums in the 1990s that called for an innovative public transportation system and a trans-alpine railway system that aims at reducing travel time between North and South Europe while seeking to be a highly attractive alternative to road transportation. This «environmentally sound» alternative aims at ensuring the quality of life of residents along the transit lines and is a welcome initiative for a more sustainable transportation system in Europe ${ }^{5}$.

5 - The direct democracy: It helps to test theories and research hypothesis about how public participation and diverse (public) value systems and stakeholder values affect landscapes. This relatively new transdisciplinary field in landscape research finds an ideal experimental ground in Switzerland where bottom-up planning has a long tradition and people are used to voicing their points of views. This participatory planning is supplemented with landscape architecture by avantgarde (landscape) architects like Corbusier and Botta ${ }^{6}$.

\section{The history of landscape research in Switzerland}

As a result of the various stimuli discussed above, landscape research in Switzerland developed under the institutional umbrella of several public Universities and Research 
Institutions, primarily in the disciplines of Geography, Botany, remote sensing, forestry, agriculture, ethnology and recently, sociology (for details see paragraph Institutes and disciplines involved). The field could profit from both the Latin notion towards landscapes ${ }^{7}$ as well as from the Anglosaxon-German view ${ }^{8}$. Due to this multiethnic mix in both research and society a variety of leading paradigms in landscape research has found its way to Switzerland thereafter being adopted, refined or altered. For a thorough analysis see Hunziker (2000). Since 1950 the following phases can be distinguished

\section{The descriptive phase after World War II}

7 The 1950s and 1960s are characterized by mostly narrative descriptions of landscape types and their cultural and physical development. The theme «Mountains and their role in the system of cultural landscapes» dominates this phase and is still an important topic today (e.g. Messerli et al., 2001; Global Mountain Biodiversity assessment ${ }^{9}$; Università della Svizzera Italiana Istituto di Storia delle Alpi ISAlp $)^{10}$. It is the period of unprecedented economic growth with only a few debates about the limits of land(scape) use and the possibility of vanishing landscapes (Egli, 1954a, 1970). Nevertheless a few visionary scientists recognized these threats and initiated an inventory of important landscape types of national importance that eventually became the official inventory in the 1970s and 1980s. At the same time, several long-term monitoring studies were started or continued. Typical research of this period is documented e.g. in Boesch (1963), Egli (1954b, 1961), Gutersohn (1950, 1960, 1968-74) and Winkler (1967a, b). Since the traditional German «Landschaftsökologie» ${ }^{11}$ (Troll, 1939, cit. in Troll, 1966) never dominated research in this country, the discipline Landscape Ecology was never taught as such until the 1970s by Prof. Leser (Leser, 1991, 1992) at Basel University (Physiogeographie und Landschaftsökologie). He viewed Landscape Ecology primarily as a natural science discipline that includes geomorphology, soils etc.

\section{The monitoring and modeling phase of the 1970s and 1980s}

Urbanization, abandonment of remote rural areas, construction of infrastructure and excessive growth of tourist demands have led to environmental problems that caused the Federal Government to implement a set of laws and decrees for the integrated conservation of landscapes and biotopes (habitats) of national importance. This was the result of several planning initiatives and corresponding research activities that were supported by academic institutions such as the Swiss Federal Institute of Forest, Snow and landscape research (WSL), the multi-disciplinary staffed institute for spatial planning (ORL) of the Swiss Federal Institute of Technology, Zürich (ETH) and others (Winkler, 1974). New technological achievements such as routine aerial photography, satellite imagery and the potential to store large datasets initiated the "quantitative» period in landscape research. Habitats were inventoried, species groups monitored, and a forest inventory was initialized in a grid of $1 \mathrm{~km}$ meshsize. Typical research projects of this period are documented in Beguin et al. (1976), Bugmann (1975, 1986), Ewald (1978, 1983, 1984), Grünig (1994), Hegg et al. (1993), Lotti et al. (1990) and Wildi and Ewald (1986). Up to present, this sound basis of long-term environmental data on mountain ecosystems is used as a reference by the international scientific community and 
inspires landscape ecologists to build outstanding models of spatial landscape development (see MAB literature from Davos and Pays d'Enhaut, Lischke et al. 2002; Kienast et al., 1999a,b; Wohlgemuth, 1998). It is also a methodological reference for many monitoring programs allover the world (e.g. IUCN, WMO).

\section{The inter- and transdisciplinary phase and the global mobile society after 1990}

9 The planning paradigms that resulted from the scientific work of the 1970-80s viewed landscapes in a mainly static way. Although necessary to avoid further damage to the cultural landscape, the planning predominantly consisted of top-down initiatives that were often conceived as contrasting with the Swiss individualism and the underlying understanding of direct democracy. Therefore they had limited success (see e.g. Muggli, 2002) ${ }^{12}$. It is this partial failure that stimulated new landscape-related research in the 1990s. New ways of dealing with the driving forces of landscape development were necessary, e.g. dealing with (a) global climate change ${ }^{13}$ (Beniston 2000; Körner, 1989, 1998, 2003; Perruchoud et al., 1999; Visconti et al., 2001), (b) a globalization of the agricultural market including a trend towards organic farming (Leimgruber, 1997, 1999; Mäder et al., 2002), (c) a trivialization of the landscape and a loss of biodiversity (Duelli et al., 1990, Duelli, 1997; Kienast et al., 1998b), (d) a global information market, (e) high spatial mobility of society and economy and the corresponding "shrinking of space» due to increased accessibility of places (Abendroth and Mestaoui, 2002, Kirsch, 1995; Racine, 1999a,b; Racine and Marengo, 2000), (f) people's loss of identification with the everyday landscape ${ }^{14}$ (Buchecker et al., 2002; Kienast et al., 1998a) and (g) withdrawal of vast parts of the population from responsibility in the public sector.

\section{New challenges for landscape research}

Given the landscape-related problems mentioned above, «re-creating» vast parts of the (European) landscape is vital. In particular, the following central question needs to be answered: What types and quality of landscapes do people want, do biological systems need, and do economic-political systems allow? Modern landscape research in Switzerland tries to tackle this question with basic, applied and transdisciplinary research (see also visions of the Scientific Community documented in SAS, 1997). Since the 1980s, numerous national and international research programs have been carried out and the expertise of Swiss landscape research in sustainable management of mountainous regions is appreciated in various projects of the European Community ${ }^{15}$ and worldwide. In an extensive review in 2003, a team of scientists from WSL supported by a panel of international experts ${ }^{16}$ have put together hot topics in landscape research in general and the specific role of Swiss landscape research. They concluded that due to the high technological level of research, the extended research in plant and animal ecology and the expertise in environment-society relationships Swiss landscape research is well-positioned in the following fields: 


\section{The interactions between stakeholder values (towards nature \& landscapes) and landscape development}

Public value systems are among the major driving forces in landscape development. These value systems are formed by cognitive processes, like preference, and processes that are bound to the place (sense of place, Gustafson, 2000). Research has to generate the basis for how these value systems are formed and how they interact in public debates about future land use. Due to strong participatory planning the corresponding Swiss expertise is impressive (see Swiss Research Programme «Landscapues and Habitats of the Alps» [http://www.snf.ch/NFP/NFP48/NFP48_AP.pdf]; Buchecker, 2002; Buchecker and Schultz, 2000; Buchecker et al., 2002; Hunziker and Kienast, 1999; Kienast, 1998; Jaeger et al., 1993; Knoepfel, 1992; Pearman, 2001; Racine, 1999a,b; Racine and Marengo, 2000).

\section{Integrating spatial aspects of population genetics with landscape ecology}

The new and promising research field of DNA analysis allows the revisiting of landscape related theories that have not been substantiated sufficiently with the technologies prior to the 1990s. They include, e.g., a potential reassessment of migration patterns of species in the postglacial landscape, a potential reassessment of metapopulation theories or a reassessment of corridor-barrier theories in landscapes. This field has become well established in Switzerland after 1998 and will most likely gain more attention in the future (Finkeldey et al., 2000; Gugerli et al., 2001; Lugon-Moulin and Hausser, 2002; Mátyás et al., 2002; Zoller et al., 1999).

\section{The impact of communications technology on landscape resources}

There is considerable effort of the Swiss Research Community to explore the environmental and social impacts of these important contemporary technologies (e.g. Fritzsche et al., 2001; Fröhlich and Axhausen, 2002; Gugerli, 1996; Widmer, 2002). Given the three major contemporary technological achievements (telecommunication, traffic, information technology and management; Kirsch, 1995), it is likely that the bounding of human activities and services to a single place is losing importance. (e.g., global communications networks). Places (see Gustafson, 2000) become interchangeable and «placelessness» of capital and people may become the rule (Yeung, 1998). At the same time alienation with this homogenized environment, along the virtual environment that is created by IT technology, will continue to increase, thereby encouraging people to seek identification with unique, real places. The latter are increasingly accessible thanks to a better traffic network and are thus threatened by homogenisation.

\section{Exploring heterogeneity in ecosystem processes across landscapes}

This topic is extensively studied in Swiss landscape research. The issues are, e.g., plantanimal interactions, nutrient flow, habitat heterogeneity in restored river landscapes, genetic diversity in natural habitats, heterogeneity in woodlands (Bebi et al., 2001; Duelli, 1997; Gillet et al., 2002; Herzog et al. 2001; Ray et al., 2002; Suter et al., 2002; 
Tockner et al., 2002; Vuilleumier and Prelaz-Droux, 2002; Wagner and Wildi, 2002). Upscaling methods are increasingly applied as well as sophisticated remote sensing techniques (for an extended overview in this field and a list of Swiss Institutes see homepage of the Remote Sensing Laboratories of the University of Zürich, for the use of the MODIS sensor see NASA Web Pages). Furthermore Swiss landscape research is well positioned to continue making significant progress in landscape models, i.e., it has the empirical data and conceptual capacity to address explicit representation of species movement and processes across landscapes.

\section{Relating landscape indicators to ecological processes}

15 Swiss landscape research has the data to rigorously relate landscape indicators to functional attributes (e.g., resilience). In this context the theme of identifying thresholds, where dramatic shifts from one system state to another take place, is an issue. Understanding the non-linear and non-stationary behavior of systems is a prerequisite to understand mechanisms of landscape change (Di Giulio et al., 2001; Freyer et al., 2000; Guisan and Theurriat, 2002; Ghosh, 2001; Hirzel et al., 2001; SAEFL, 1997)

\section{Using the legacy of past land use to explain variation in present-day landscapes}

16 This paradigm is extensively used in Swiss landscape research in order to avoid misinterpretation of the observed change in environmental features. The historical approach is possible due to well preserved historical and paleoecological archives. It is also an ideal means to address issues such as predictability, management options or the identification of weak signals to predict future changes (Bürgi and Turner, 2002; Cosgrove, 1984; Crumley, 1998; Borcard et al., 1995; Bürgi and Russell, 2001; Ewald, 1978, 2001; Hall, 2001; Kienast, 1993; Walter, 1984). Landscape history moreover is applied in outreach programs in the context of participatory planning and in restoration projects (Marcucci, 2000).

\section{Risk assessment}

Due to the fact that the mountainous terrain of Switzerland creates a set of disturbances (e.g. debris flow, avalanches) living with and understanding natural hazards has a long tradition. Risk assessment is routinely performed to protect infrastructure and to assess potential impacts of harmful substances or global change on ecosystems. The corresponding research expertise is considerable (e.g. Bartelt and Lehning, 2002; Dapples et al., 2002; Kienast et al., 1996; Laternser and Schneebeli, 2002).

\section{Communicate research to the public and to policy makers}

This is one of the strengths of landscape research in Switzerland. It stems from the fact that the influence of stakeholder values and the public on landscape development was early recognized in landscape research. Thus a tradition of transdisciplinary studies and extension service could be established at various research institutions (e.g. Dept.of 
Environmental Sciences ETHZ, http://www.umnw.ethz.ch). Successful communication requires up-front visualization and scenario tools. Several Swiss Labs are successfully working on these sophisticated techniques (Hirtz et al., 1999; Lange, 2001).

\section{Institutes and disciplines involved}

19 Due to the broad multidisciplinary character of landscape research, the corresponding expertise can be found at various universities and research institutions, primarily in the departments of geography, botany or environmental sciences. Research institutions in Switzerland that specialize in landscape research (paysage, paesaggio, Landschaft) are $\mathrm{WSL}^{17}$, which is the largest institution for landscape research, the professorship for nature and landscape conservation ${ }^{18}$, the Network for urban areas and landscape $(\mathrm{NLS})^{19}$, various chairs at the Dept. of Rural Engineering at EPFL ${ }^{20}$ and the chair for landscape architecture ${ }^{21}$ that has achieved a high reputation in design of heavily sculptured landscapes in urban areas. Landscape architecture is also taught at the two universities of applied sciences in Rapperswil ${ }^{22}$ and Lullier ${ }^{23}$. Table 1 yields further information about institutions in Switzerland with landscape-related activities. Switzerland has an active regional representation of the International Association for Landscape Ecology (IALE) ${ }^{24}$ as well as active chapters in Landscape Architecture and spatial planning.

Table 1. Some leading Swiss institutions in landscape research.

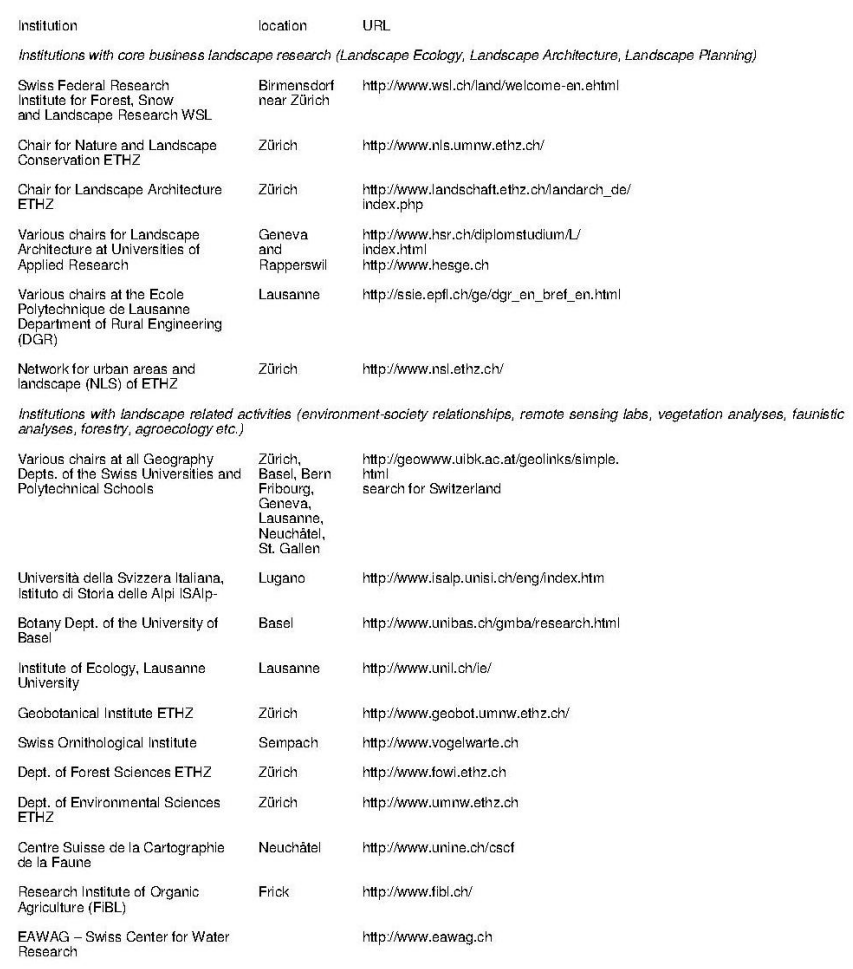




\section{BIBLIOGRAPHY}

ABENROTH M., MESTAOUI N. (2002), http:www.lab-au.com.

BARTELT P., LEHNING M. (2002), «A physical SNOATACK model for the Swiss avalanche warning Part I: numerical model», Cold. Reg. Sci. Technol. 35 (3), pp. 123-145.

BASTIAN O., STEINHARDT U. (eds.) (2003), Development and perspectives of landscape ecology with a foreword by Zev Naveh, Kluwer Academic Publisher, Dordrecht, Boston, London.

BEBI P., KIENAST F., SCHÖNENBERGER W. (2001) «Assessing structures in mountain forests as a basis for investigating the forests' dynamics and protective function», Forest Ecol. Manag. 145 (1-2), pp. 2-14.

BÉGUIN C., HEGG O., ZOLLER H. (1976), «Utilisation d'écogrammes pour une étude écophytosociologique de la Suisse; cartographie de la distribution et de la valeur de protection des principaux groupements», Doc. Phytosociol. 19-20, pp. 89-98.

BENISTON M. (2000), Environmental Change in Mountains and Uplands, Arnold/Hodder and Stoughton/Chapman and Hall Publishers, London, UK, and Oxford University Press, New York, USA.

BOESCH H. (1963), Flugbild der Schweizer Stadt, Bern, Kümmerly \& Frey.

BORCARD D., GEIGER W., MATTHEY W. (1995), «Oribatid mite assemblages in a contact zone between a peat-bog and a meadow in the Swiss Jura (Acari, Orbiatei) - Influence of landscape structures and historical processes», Pedobiologia, 39, pp. 318-330.

BUCHECKER M., HUNZIKER M., KIENAST F. (2002), «Participatory Landscape Development Getting the Residents Involved», Landscape and Urban Planning 973, pp. 1-19.

BUCHECKER M., SCHULTZ B. (2000), «Lebendiges Dorf, lebendiges Quartier. Wie Bewohnerinnen und Bewohner die Entwicklung mitgestalten. Ein Leitfaden», WSL Publikation, Sonderformat.

BUCHECKER M. (2002), «Withdrawal from the public: between social control and individualism», in MIRA R. G. et al. (Eds), Culture, quality of life and globalization, Book of Proceedings of 17th Conference of the international Association for People-Environment Studies.

BUGMANN E. (1975), Die formale Umweltqualität: ein quantitativer Ansatz auf geographisch-ökologischer Grund lage, Solothurn, Vogt-Schild.

BUGMANN E. (1986), «Die Bestimmung des bio-dynamischen Potentials der Landschaft», Publikationen der Forschungsstelle für Wirtschaftsgeo graphie und Raumplanung an der Hochschule St. Gallen, Nr. 10.

BÜRGI M., RUSSELL E.W.B. (2001), «Integrative methods to study landscape changes», Land Use Policy, 18, pp. 9-16.

BÜRGI M., TURNER M. (2002), «Factors and processes shaping land cover and land cover changes along the Wisconsin River, USA», Ecosystems 5, pp. 184-201.

COSGROVE D.E. (1984), Social formation and symbolic landscape, Madison, University of Wisconsin Press.

CRUMLEY C.L. (1998), «Foreword», in BALEE W.(ed.), Advances in historical ecology, pp. ix-xiv, New York, Columbia University Press. 
DAPPLES F., LOTTER A.F., VAN LEEUWEN J.F.N. et al. (2002), «Paleolimnological evidence for increased landslide activity due to forest clearing and land-use since $3600 \mathrm{cal} \mathrm{BP}$ in the western Swiss Alps», J. Paleolimnol. 27 (2), pp. 239-248.

DI GIULIO M., EDWARDS P.J., MEISTER E. (2001), «Enhancing insect diversity in agricultural grasslands: the roles of management and landscape structure», J. Applied Ecol. 38 (2), pp. 310-319

DUELLI P. (1997), «Biodiversity evaluation in agricultural landscapes: An approach at two different scales», Agr. Ecosyst. Environ 62, pp. 81-91.

DUELLI P., STUDER M., MARCHAND I., et al. (1990), «Population-movements of Arthropods between natural and cultivated areas», Biol. Conserv. 54 (3), pp.193-207.

EGLI E. (1954a), Mahnworte zur Rheinau-Frage: drei Reden gehalten am 3. Dezember 1953, Zürich, Lienberger.

EGLI E. (1954b), Die Schweiz: eine Landeskunde, 2. ed., Bern, Haupt.

EGLI E. (1961), Erlebte Landschaft: die Heimat im Denken und Dasein der Schweizer, Artemis.

EGLI E. (1970), Natur in Not: Gefahren der Zivilisationslandschaft, Internal report, Univ. Zürich.

EWALD K. C. (1978), «Der Landschaftswandel - zur Veränderung schweizerischer Kulturlandschaften im 20. Jahrhundert», in Tätigkeitsber. d. Naturforsch. Ges. Baselland, Bd. 30, 55-308, und Sonderdruck als: Ber. d. Eidgenössischen Anstalt für das forstliche Versuchswesen, 8903 Birmensdorf, Nr. 191.

EWALD K. C. (1983), «Landschaften und Naturdenkmäler von nationaler Bedeutung», Schweiz, Suisse, Svizzera, Switzerland, Jg. 56, Nr. 9.

EWALD K. C. (1984), «Der «Basler Natur-Atlas» - zur Inventarisierung von Natur und Landschaftsteilen im Kanton Basel-Stadt und einigen angrenzenden Gebieten», Regio Basiliensis, Jg. 25, Nr. 2/3, pp. 199-206.

EWALD K.C. (2001), «The neglect of aesthetics in landscape planning in Switzerland», Landscape Urban Plan. 54 (1-4), pp. 255-266.

FINKELDEY R., BONFILS P., LANDOLT R. (Eds) (2000), «Forest Gene Reserves / Forstliche Genreservate. Proceedings of the Forum 'Genetik-Wald-Forstwirtschaft' held at the Swiss Federal Research Institute WSL in Birmensdorf, Switzerland», For. Snow Landsc. Res. 75, 1/2, pp. 1-284.

FREYER B., REISNER Y., ZUBERBÜHLER D. (2000), «Potential impact model to assess agricultural pressure to landscape ecological functions», Ecol. Model, 130 (1-3), pp. 121-129.

FRITZSCHE B., FREY T., REY U. (2001), Historischer Strukturatlas der Schweiz. Die Entstehung der modernen Schweiz, Zürich, hier + jetzt, Verlag für Kultur und Geschichte.

FRÖHLICH P., AXHAUSEN K.W. (2002), Development of car-based accessibility in Switzerland from 1950 through 2000, 2nd STRC Conference, Ascona, March 20-22, 2002.

GHOSH S. (2001), «Nonparametric trend estimation in replicated time series», J. Stat. Plan. Inference 97, pp. 263-274.

GILLET F., BESSON O., GOBAT J.-M. (2002), «PATUMOD : a compartment model of vegetation dynamics in wooded pastures», Ecological Modelling 147, pp. 267-290.

GUGERLI D. (1996), Redeströme. Zur Elektrifizierung der Schweiz 1880-1914, Zürich, Chronos-Verlag. GUGERLI F., SPERISEN C., BÜCHLER U., MAGNI F., GEBUREK T., JEANDROZ S. \& SENN J. (2001), «Haplotype variation in a mitochondrial tandem repeat of Norway spruce (Picea abies) 
populations suggests a serious founder effect during postglacial re-colonisation of the western Alps», Mol. Ecol. 10, pp. 1255-1263.

GUISAN A., THEURILLAT J.-P. (2001), «Assessing alpine plant vulnerability to climate change: A modeling perspective», Integrated Assessment 1, pp. 307-320.

GUSTAFSON P. (2000), «Meanings of Place: Everyday Experience and Theoretical Conceptualizations», Journal of Environmental Psychology, 21, pp. 5-16.

GUTERSOHN H. (1950), Landschaften der Schweiz, Büchergilde Gutenberg.

GUTERSOHN H. (1960), «Die Geographie als Grundlage der Orts-, Regional-und Landesplanung», Arbeiten aus dem Geographischen Institut, Eidgenössische Technische Hochschule Zürich, Nr. 36.

GUTERSOHN H. (1968-1974), Geogra phie der Schweiz, Bern, Kümmerly \& Frey.

GRÜNIG A. (1994), Mires and man: mire conservation in a densely populated country - the Swiss experience : excursion guide and symposium proceedings of the 5th Field Symposium of the International Mire Conservation Group (IMCG) to Switzerland 1992, Birmensdorf, Swiss Federal Institute for Forest, Snow and Landscape Research.

HALL M. (2001), «Repairing Mountains: Restoration, Ecology, and Wilderness in TwentiethCentury Utah», Environmental History, 6, pp. 574-601.

HEGG O., BÉGUIN C., ZOLLER H. (1993), Atlas de la végétation à protéger en Suisse, Ed. Par l'Office fédéral de l'environnement, des forêts et du paysage, Berne, $160 \mathrm{pp}$.

HERZOG F., LAUSCH A., MÜLLER E. et al. (2001), «Landscape metrics for assessment of landscape destruction and rehabilitation», Environ. Manage 27 (1), pp. 91-107.

HINTERMANN U. (1991), Schlussbe richt zum Inventar der Moorlandschaften, EDI/BUWAL (Hrsg.), Bern.

HIRTZ PH., HOFFMAN H., NÜESCH D. (1999), «Interactive 3D Landscape Visualization: Improved Realism Through Use of Remote Sensing Data and Geoinformation», Proceedings of Computer Graphics International 1999, Canmore, Alberta, Canada, pp. 101-108.

HIRZEL A.H., HELFER, V., METRAL F. (2001), «Assessing habitat-suitability models with a virtual species», Ecol. Model. 145 (2-3), pp. 11-121.

HUNZIKER M. (2000), Einstellungen der Bevölkerung zu möglichen Landschaftsentwicklungen in den Alpen, Birmensdorf, Eidgenössische Forschungsanstalt WSL. 157 S

HUNZIKER M., KIENAST F. (1999), «Impacts of changing agricultural activities on scenic beauty - a prototype of an automated rapid assessment technique», Landscape Ecology 14, pp. 161-176.

JAEGER C., DÜRRENBERGER, G. KASTENHOLZ, H. TRUFFER B. (1993) «Determinants of Environmental Action with Regard to Climatic Change», Climatic Change 23, pp. 193-211.

KIENAST F. (1993), «Analysis of historic landscape patterns with a Geographical Information System- a methodological outline», Landscape Ecology, 8, pp.103-118.

KIENAST F. (1998), «Towards a socially accepted, sustainable management of agricultural landscapes», in SCHELLNHUBER H.M. and WENZEL V., (ed.), Earth System Analysis: Integrating Science for Sustainability, Springer.

KIENAST F., BRZEZIECKI B., WILDI O. (1996), «Long-term adaptation potential of Central European mountain forests to climate change: a GIS-assisted sensitivity assessment», Forest Ecology and Management 80, pp. 133-153. 
KIENAST F., FRITSCHI J., BISSEGGER M., ABDERHALDEN W. (1999a), «Modelling successional patterns of high-elevation forests under changing herbivore pressure - responses at the landscape level», Forest Ecology and Management 120, pp. 35 - 46.

KIENAST F., FRITSCHI J., BISSEGGER M., et al. (1999b), «Modeling successional patterns of highelevation forests under changing herbivore pressure - responses at the landscape level», Forest Ecol. Manag. 120 (1-3), pp. 35-46.

KIENAST F., HUNZIKER M., BUCHECKER M. (1998a), «Landschaft für die Bevölkerung» («Un paysage pour la population»), Anthos 2/98, pp. 32 - 37.

KIENAST F., WILDI O., BRZEZIECKI B. (1998b), «Potential impacts of climate change on species richness in mountain forests - an ecological risk assessment», Biological Conservation 83, pp. 291 305.

KIRSCH S. (1995), «The incredible shrinking world - technology and the production of space», Environment and Planning D- Society \& Space 13 (5), pp. 529-555.

KNOEPFEL P. (1992), «Zur unzumutbaren politischen Rolle der Naturwissenschaften in der Umweltdebatte», GAIA 1, pp. 175-180.

KÖRNER C. (1989), «The nutritional status of plants from high-altitudes - a world-wide comparison», Oecologia 81, pp. 379-391 1989

KÖRNER C. (1998), «A re-assessment of high elevation treeline positions and their explanation», Oecologia 115 (4), pp. 445-459.

KÖRNER C. (2003), «Carbon limitation in trees», J. Ecol. 91, pp. 4-17.

LANGE E. (2001), «The limits of realism: perceptions of virtual landscape», Landscape and Urban Plan. 54, pp. 163-182.

LATERNSER M., SCHNEEBELI M. (2002), «Temporal trend and spatial distribution of avalanche activity during the last 50 years in Switzerland», Nat. Hazards 27 (3), pp. 201-230.

LEIMGRUBER W. (1997), «L'agriculture en Suisse: problèmes et politique», in Treballs de la Societat Catalana de Geografia, No. 44, vol. XII, pp. 71-84

LEIMGRUBER W. (1999), «Border effects and the cultural landscape: the changing impact of boundaries on regional development in Switzerland», in KNIPPENBERG H. \& MARKUSSE J. (eds.), «Nationalising and denationalising European border regions, 1800-2000: views from geography and history», Geojournal Library 53, pp. 199-221. Dordrecht, Kluwer, 1999.

LESER H. (1991), Landschaftsökologie, Kap. 2: Landschaftsökologie - Fach oder Fachbereich?

LESER H. (1992), «Landscape Ecology», in «40 Years After: German Geography. Development Trends and Prospects 1952-1992. A Report to the International Geographical Union, edited by Eckart Ehlers»; Suppl. Vol. to the Series Applied Geography and Development, Bonn - Tübingen, pp. $99-126$.

LINDEMANN-MATTHIES P. (1995), «Biodiversity in schools - current efforts in environmental education in Switzerland», in Supplement to Bulletin of the Ecological Society of America 76(2), p. 155.

LINDEMANN-MATTHIES P. (2000), «Species matter: biodiversity in education», IALE Bulletin 18(6), pp. 1-2.

LINDEMANN-MATTHIES P. (2001), «The influence of an educational program on children's perception of biodiversity», The Journal of Environmental Education. 
LISCHKE H., LOTTER A., FISCHLIN A. (2002), «Untangling a post-glacial pollen record with forest model simulations and independent climate data», Ecological Modelling 150, pp. 1-21.

LOCHER R. (1991), Die Moorlandschaften der Schweiz, EDI/BUWAL (Hrsg.), Bern, 104 S.

LOTTI TH., KATHRIN P., HERTZ J., BÄCHTOLD H.-G. (1990), «Ökologische Planung: Ergebnisse der Fallstudie Bündner Rheintal», ORL-Bericht 76, vdf Hochschulverlag ETH Zürich.

LUGON-MOULIN N., HAUSSER J. (2002), «Phylogeographical structure, postglacial recolonization and barriers to gene flow in the distinctive Valais chromosome race of the common shrew (Sorex araneus)», Mol. Ecol. 11 (4), pp. 785-794.

MÄDER P., FLIESSBACH A., DUBOIS D., GUNST L., FRIED P. NIGGLI U. (2002), «Soil Fertility and Biodiversity in Organic Farming», Science 296, pp. 1694-1697.

MARCUCCI D.J. (2000), «Landscape history as a planning tool», Landscape and Urban Planning 49, pp. 67-81.

MARENGO M., ALAIMO A. (1998), Gli itinerari della memoria. Il paesaggio della Sicilia nei racconti degli immigrati siciliani a Losanna $(\mathrm{CH})$, Convegno «La costruzione del paesaggio siciliano, Geografi e scrittori a confronto», Palermo, 18-20 marzo 1998.

MÁTYÁS G., BONFILS P., SPERISEN C. (2002), «Autochthon oder allochthon? Ein molekulargenetischer Ansatz am Beispiel der Eichen (Quercus spp.) in der Schweiz», Schweiz. Z. Forstwes. 153, 3, pp. 91-96.

MESSERLI B, VIVIROLI D, WEINGARTNER R. (2001), «A new typology for mountains and other relief classes: An application to global continental water resources and population distribution», Mt. Res. dev. 21 (3) , pp. 307-307.

MÜLLER H.R, FLÜGEL M. (1999), «Tourismus und Ökologie - Wechselwirkungen und Handlungsfelder», Berner Studien zu Freizeit und Tourismus Nr. 37.

PEARMAN P.B. (2001), «Conservation value of independently evolving units: sacred cow or testable hypothesis?», Conserv. Biol. 15, pp. 780-783.

PERRUCHOUD D., KIENAST F., KAUFMANN E., BRÄKER O.U. (1999), «20th Century Carbon Budget of Forest Soils in the Alps», Ecosystems 2, pp. 320-337.

RACINE J.B. (1999a), «Entre logiques de concentration et logiques d'éclatement: la ville ordinaire en transition», in COMMERÇON N. et GEORGE P. (éds.), Villes de transition, Paris, Anthropos, pp. 203-217.

RACINE J.B. (1999b), «The foreigner and the city; from co-presence to Interaction, in Search of intercultural Places in Lausanne (Switzerland)» (avec Christophe Mager), in AGUILAR A. \& ESCAMILLA I. (eds.), Problems of Megacities: Social inequalities, Environmental risk and Urban governance, Universitad Nacional Autonoma de México, UNAM, Commission of Urban Development and Urban Life, IGU. pp. 477-498.

RACINE J.B., MARENGO M. (2000), «Migrations et relations interculturelles: recherches sur les lieux urbains de l'interculturalité», in CENTLIVRES P. et GIROD I. (éds.), Les défis migratoires, Colloque Cluze, Neuchâtel, Seismo, pp. 349-357.

RAY N., LEHMANN A., JOLY P. (2002), «Modeling spatial distribution of amphibian populations: a GIS approach based on habitat matrix permeability», Biodivers. Conserv. 11 (12), pp. 2143-2165.

SAEFL (1997), Criteria and Indicators for Sustainable Forest Management in Switzerland, Swiss Agency for Environment, Forests and Landscape, Bern, 80 p. 
SUTER W., GRAF, R.F., HESS R. (2002), «Capercaillie (Tetrao urogallus) and avian biodiversity: Testing the umbrella-species concept», Cons. Biol. 16, pp. 778-788.

SWISS ACADEMY OF SCIENCES (SAS) (1997), Research on Sustainability and Global Change - Visions in Science Policy by Swiss Researchers (http://www.proclim.ch/Reports/SP/Visions/Visions_E.html)

TOCKNER K., WARD J.V., EDWARDS P.J. et al. (2002), «Riverine landscapes: an introduction», Freshwater Biol. 47 (4), pp. 497-500.

TROLL C. (1966), Landschaftsökologie als geographisch-synoptische Naturbe trachtung.

TRUFFER B., MARKARD J., WUSTENHAGEN R. (2000), «Eco-labeling of electricity - strategies and tradeoffs in the definition of environmental standards», Energ. Policy 29 (11), pp. 885-897.

TURNER M.G., GARDNER R.H., O'NEILL R.V. (2001), Landscape ecology in theory and practice: pattern and process, Springer-Verlag, New York.

VISCONTI G., BENISTON M., IANNORELLI E.D, BARBA D. (2001), «Global Change and Protected Areas», in ed. by BENISTON M. (ed.), Advances in Global Change Research, Kluwer Academic Publishers, Dordrecht/The Netherlands and Boston/USA, 521 pp.

VUILLEUMIER S., PRELAZ-DROUX R. (2002), «Map of ecological networks for landscape planning», Landscape Urban Plan. 58 (2-4), pp. 157-170.

WAGNER H.H., WILDI O. (2002), «Realistic simulation of the effects of abundance distribution and spatial heterogeneity on non-parametric estimators of species richness», Eco Science 9 (2), pp. 241-250.

WALTER F. (1984), «Perception of Landscape and influence on space in 18th-century Switzerland», Ann. Econ. Soc. Civil. 39, pp. 3-29.

WIDMER J.P. (2002), Accessibility by air passenger transport related to Switzerland, 2nd STRC Conference, Ascona, March 20-22, 2002.

WILDI O., EWALD K. (1986), Der Naturraum und dessen Nutzung im alpinen Tourismusgebiet von Davos Ergebnisse des MAB-Projektes Davos, Eidgenössische Anstalt für das forstliche Versuchswesen.

WINKLER E. (1967a), «L'aménagement du territoire suisse», Arbeiten aus dem Geographischen Institut, Eidgenössische Technische Hochschule Zürich, Nr. 45, pp. 58-94.

WINKLER E. (1967b), «Wald- und Landschaftspflege», Arbeiten aus dem Geographischen Institut, Eidgenössische Technische Hochschule Zürich, Nr. 46, 10p.

WINKLER E. (1974), Teilleitbild Landschaftsschutz: landesplanerische Leitbilder der Schweiz, Institut für Orts-, Regional- und Landesplanung an der ETHZ.

WOHLGEMUTH T. (1998), «Modelling floristic species richness on a regional scale: a case study in Switzerland», Biodiv. Cons. 7, pp. 159-177.

YEUNG H.W.C. (1998), «Capital, state and space: contesting the borderless world», Transactions of the Institute of British Geographers 23 (3), pp. 291-309.

ZOLLER S., LUTZONI F., SCHEIDEGGER C. (1999), «Genetic variability within and among populations of the threatened foliose lichen Lobaria pulmonaria in Switzerland and implications for its conservation», Mol. Ecol. 8, pp.2049-2059. 


\section{NOTES}

1. Bundesamt für Statistik (2002) Statistisches Jahrbuch der Schweiz, Zürich, NZZ Verlag.

2. http://www.swisstopo.ch/en/digital/adsi.htm or http://www.eda.admin.ch/ canada_all/e/home/facts/lands.html

3. http://www.csf-mv.ethz.ch/; http://www.tcp.ch/cultura/Hermann_Hesse/

Mte_Verit_/mte_verit_html

4. http://www.biosphaere.ch

5. http://www.blsalptransit.ch

6. http://www.vitruvio.ch

7. http://indicateur.paysage.free.fr/

8. A good example for the differing views was elaborated in an empirical landscape perception study in the Swiss National Park where people were asked to report on the appearance of decaying mountain forests (http://www.wsl.ch/land/society/L-assessen.ehtml). It was evident that the latin valuation of this naturally occurring successional step was significantly different from the Anglo-German valuation. Thus we conclude that not only the view of a park is different but also the view of the every-day landscape.

9. http://www.unibas.ch/gmba/research.html

10. http://www.isalp.unisi.ch/eng/index.htm

11. We view Landscape Ecology as one specific stimulus in the field of Landscape Research

12. http://www.vlp-aspan.ch/files/pdf/landusech.pdf

13. http://www.wsl.ch/land/products/klimaanimation/

14. The landscape where people spend most of their time, i.e. in their homes, at work, and commuting.

15. Since 2002 Switzerland is full partner of the EU research programs. The bilateral agreements strengthen the relationship between Switzerland and the European Union and facilitate mutual market access. The agreements cover the following seven areas: Free Movement of Persons, Overland Transport, Air Transport, Agriculture, Public Procurement Markets, Technical Barriers to Trade and Research.

16. W. Haber, TU Munich; M. Turner, Univ. Wisconsin, Madison; R. Weibel, Univ. Zürich; J. Saborowski, Univ. Göttingen; S. Heiler, Univ. Konstanz; L. Orlóci, Univ. Western Ontario; A. Watt, CEH Banchory; T. Hartig, Uppsala Univ.

17. http://www.wsl.ch

18. http://www.nls.umnw.ethz.ch/

19. http://www.nls.ethz.ch

20. http://www.epfl.ch

21. http://www.landschaft.ethz.ch/en/

22. http://www.l.hsr.ch/

23. http://www.hesge.ch

24. http://www.wsl.ch/land/iale/ 


\section{ABSTRACTS}

Landscape research in Switzerland enjoys a high technological and intellectual standard. It is influenced by both region-independent stimuli (e.g. remote sensing, sociology, population biology or statistics), and stimuli that have a strong bounding to the regional context. Regionspecific stimuli for Landscape Research in Switzerland are:

- the highly heterogeneous topography of the mountains as prerequisite to develop and test landscape-related theories,

- the contrasting individualistic lifestyles of a multi-ethnic society that generates contrasting notions towards landscapes and thus contrasting methods in landscape research,

- the long tradition of environmental research, monitoring and education and the high public motivation to support landscape-related research, as well as

- the direct democracy where Landscape Research finds an ideal experimental ground to test theories and research hypothesis about how public participation or diverse (public) value systems and stakeholder values affect landscapes.

Landscape research in Switzerland developed under the institutional umbrella of several public universities and research Institutions, primarily in the disciplines of geography, botany, remote sensing, forestry, agriculture, ethnology and sociology.

Modern landscape research in Switzerland is performed as basic as well as applied research. It is well-positioned in the following fields: (1) the interactions between stakeholder values (towards nature \& landscapes) and landscape development, (2) integrating spatial aspects of population genetics with landscape ecology, (3) the impact of communications technology on landscape resources, exploring heterogeneity in ecosystem processes across landscapes, relating landscape indicators to ecological processes, landscape historical approaches, and communicating research to the public and to policy makers.

Die Landschaftsforschung in der Schweiz ist sowohl technologisch als auch intellektuell hoch entwickelt. Sie wird geprägt von überregional wirkenden Forschungsstimuli, wie z.B. der Fernerkundung, der Soziologie, der Populationsbiologie oder der Statistik aber auch von Stimuli, die einen starken regionalen Bezug haben. Letztere sind:

- die unterschiedliche Topographie des Gebirges als günstige Voraussetzung für das Entwickeln und Testen von landschaftsrelevanten Theorien,

- die unterschiedlichen, individuellen Lebensstile einer multi-kulturellen Gesellschaft, welche bewirken, dass Landschaften ganz unterschiedlich wahrgenommen, und mit gegensätzlichen Methoden untersucht werden,

- die langjährige Tradition im Erforschen und Beobachten der Umwelt sowie in der Umwelterziehung und die grosse Bereitschaft der Öffentlichkeit, landschaftsrelevante Forschung zu unterstützen, und

- die direkte Demokratie, die für die Landschaftsforschung einen idealen experimentellen Raum zum Testen von Theorien und Hypothesen darstellt, z.B. darüber, wie die öffentliche Mitbeteiligung oder die unterschiedlichen Werthaltungen der Akteure die Landschaft beeinflussen.

Die Landschaftsforschung in der Schweiz entwickelte sich an unterschiedlichen Institutionen und Universitäten, hauptsächlich in den Disziplinen Geographie, Botanik, Fernerkundung, Forstund Agrarwissenschaften, Ethnologie und Soziologie.

Die moderne Landschaftsforschung in der Schweiz versteht sich als grundlagen orientierte und angewandte Forschung. Sie ist auf folgenden Gebieten führend: (1) Analyse der Zusammenhänge zwischen den unterschiedlichen Werthaltungen der Akteure (gegenüber Natur \& Landschaft) und 
der Landschaftsentwicklung, (2) Integration der räumlichen Aspekte der Populationsgenetik in die Landschaftsökologie, (3) Auswirkungen moderner Kommunikationstechnologien auf die Landschaft, (4) Analyse von ökologischen Prozessen in der realen Landschaft, (5) Indikatoren zur Beschreibung des Landschaftszustandes und ihre Verknüpfung mit ökologischen Prozessen, (6) Landschaftsgeschichte, und (7) Umsetzung von Wissen für die Öffentlichkeit und die Politik.

\section{INDEX}

Keywords: land-use, history, Switzerland, Landscape Research, multi-ethnic society, research hot topics, research agenda, global change, landscape development

Schlüsselwörter: Landnutzung, Geschichte, Schweiz, Landschaftsforschung, multi-kulturelle Gesellschaft, Forschungsthemen, Landschaftsentwicklung

\section{AUTHORS}

\section{FELIX KIENAST}

Swiss Federal Institute of Forest, Snow and Landscape Research (WSL), CH-8903 Birmensdorf, Switzerland, Corresponding author, kienast@wsl.ch

\section{MATTHIAS BÜRGI}

Swiss Federal Institute of Forest, Snow and Landscape Research (WSL), CH-8903 Birmensdorf, Switzerland

\section{OTTO WILDI}

Swiss Federal Institute of Forest, Snow and Landscape Research (WSL), CH-8903 Birmensdorf, Switzerland 